\title{
Relationship between Export, Import, Foreign Direct Investment and Economic Growth in Indonesia
}

\author{
${ }^{1}$ Imam Mukhlis, ${ }^{2}$ Lutfi Asnan Qodri \\ 1Universitas Negeri Malang, Malang, Indonesia, $\square$ imam.mukhlis.fe@um.ac.id \\ ${ }^{2}$ Universitas Negeri Malang, Malang, Indonesia
}

\begin{abstract}
This study aims to analysis the relationship between export, import, foreign direct investment and economic growth using time series data during 1980 to 2017 in Indonesia. This paper applied vector error correction model (VECM) to estimate the relationship between variables. The empirical results showed that foreign direct investment have significant effect to economic growth in Indonesian economy. Meanwhile, in the short run there were not significantly affect between export and import to economic growth in Indonesian economy. In model specification, the model was invalid because insignificantly coeficient of error correction term.

Keywords: Economic Growth; Export-Import; Foreign Direct Investment, Vector Error Correction Model.
\end{abstract}

\section{Introduction}

Globalization has a consequence for each country to run an open economy system. Information can be received easily between countries without any limitation and each country provides an open access to the other countries. In the other word, it illustrates that each country exhausts to attain their country's need (Mukhlis, et al,2018). The fulfillment of goods and services has improved and it proposes a new circumstance in a free trade. Export and import are the term that covered a trading activity between countries. Export is goods and services produced by a country and purchased by civilian in another country and vice versa for import. In the past two decades, foreign direct investment also has been studied as an important factor for growth and development. In the recent years, asian countries have attracted a significant part of the foreign direct investment (FDI) of the world.

Neither export not import play a critical role both for under-develop countries and develop countries. Yin and Yin (2005) remarked that export has improved investment capital intensive and productivity in developing countries. Moreover, Hee and Lee (2018) stated that export trade could enlarge trade balance of a country which will affect to economic growth. In addition, Salvatore (1990) pointed that export stimulates an economic growth for under develop country whilst high rates of import potentially affects balance trade deficit. According to the Law of the Republic of Indonesia, import is the activity of entering goods into the customs area. Literally, imports can be interpreted as the activities of entering goods from foreign country into the customs territory of country. Vohra (2001) examine about relationship between export and economic growth in India, Pakistan, Phillipines, Malaysia, and Thailand ranging 1973 to 1993. The result indicated that when a country has achieved some level of economic development than export have a positive and significant impact on economic growth.

Tong (1995) explored the relationship between economic growth and import, the result that import at different times contributed to economy differently, but as a whole, there was a positive correlation between import and economic growth. Humpage (2000) on other side, stressed that import does not lower economic growth. Cause that imports and economic growth are positively correclated, with causality running in both directions. 
In Malaysia, Kogid et al. (2011) investigated the association between economic growth and imports. They used annual data from 1970-2007. Cointegration of variables has been checked by using Engle-Granger test and Johansen's cointegration test which suggests no long-run relationship. Granger's causality test and Toda-Yamamoto test for causality have been employed to check the causality direction between variables. The result of both tests suggested bidirectional causality between economic growth and imports. The study concludes that imports of Malaysia contribute towards its economic growth.

The relationship between export and economic growth of countries in Asia was also cared for and studied by many economists. Kholis (2012) Using pooled least square method, this study showed that export growth has a positive effect on economic growth in Indonesia but import has a negative impact on economic growth. This study also explains if export was the main driver of economic growth. Faridi (2012) studied the capacity of export to contribute to economic growth in Pakistan during period $1972-2008$.

Numerous studies related to export and economic growth conducted by several authors like Ekanayake (1999); Md and Suleiman (2016); Mohsen (2015); Ekanayake (1999) remarked that export has significantly impact on economic growth. At the same time, the study result did not show any relationship between economic growth and export in the region under study.

Both export and import have an acquaintance with factors that affect to trade balance in a country (Babatunde, 2014). Export and import is highly suggested for several reasons like improving national income and economic growth, enhancing cooperation between countries, engaging a job opportunity, and expanding market for local products. Theoretically, an increasing export in a country will promote to the higher an economic growth. In the context of Indonesia, the commodities of export are dominated by raw goods which affect to the unpredictable price fluctuation.

Mukhlis and Simanjuntak (2014) examined the relationship between foreign direct investment with economic growth in Indonesia for 1981-2012. The result show that there was not relationship between two variables in the long run. Blomstorm and Kokko (1996) asserted that foreign direct investment (FDI) provides economic growth in developing countries. But studied Carkovic and Levine (2005) and Putra. Meanwhile, Gorg and Greenaway (2004) examined that foreign direct investment (FDI) does't have any influence on economic growth.

In the other hand if seen from the causality from foreign direct investment to export it is to much result in any research. But majority of the result from any studied explained that forreign direct investment can be considered to be as a significant. Like analyzing effect of the foreign direct inventmen inflow to the export performance of fourthteen transition economies in Central and Eastern Europe (CEE). Kutan and Vuksic ( 2007) examined that foreign direct inventment has improved the export performance of the host economies by increasing their supply capacities. Some studied has the research indicated a two way causality Liu, et. al. (2001); Zhang and Felmingham (2001); Ekanayake, et al (2003); Balimoune-Lutz (2004); Dritsaki, et al. (2004); Zhang (2006); Alfaro, et al. (2000) explained a directional causal relationship between FDI and export with a direction from foreign direct investment to export and reversely causal relationship.

Foreign direct investment also has causality with an import in turkey, Onkuwa and Zoral (2009) examined about how foreign direct investment has a relationship to import in the short run and long run. In the short run turkish import demand appears to be driven by appreciation of Turkish Lira and rising domestic price level of good and services. As the Lira continued to appreciate the demand for import will continue to rise, suggesting trade deficits and huge import bills which further reduces Turkish foreign reserve. In the long run, changes in the relative exchanges rate would not affect the import demand and if any it would leave the import bill unchanged. 
Based on this background, this study aims to analyze relationship between exports, imports, foreign direct investment (FDI) and economic growth in Indonesia in the period 1980-2017.

\section{Methods}

This study used quantitative method. Quantitative method is a scientific approach that views a reality that can be clarified, concrete, observable and measurable, the relationship of variables is causal and the research data is in the form of numbers. This type of research using secondary time series data during 1980-2017. The data set consist of observation for exports of good services (current US\$), omport of goods and services (current US\$), foreign direct investment (FDI), and Economic Growth in Indonesia. All data set are taken from World Development Indicators 2018.

The VECM model is a special case of the VAR model that only applies systems that have stationary and cointegrated conditions. The use of the Vector Error Correction Model (VECM) in estimating empirical phenomena can provide benefits especially in conducting analysis both in the short and long term. While the variables used in this study are as follows:

a. Export (EKS) is the sale of products and services from Indonesia to foreign countries. In this study exports were accumulated both from oil and gas exports and non-oil and gas.

b. Import (IMP) is the purchase of goods and services from abroad entering Indonesia. The import value in this study is also the accumulation of oil and gas and non-oil imports.

c. Foreign Direct Investment (FDI) is a form of long-term investment in companies located in other countries.

d. Economic Growth (PEK) is a percentage increase in economic growth every year.

Whereas the stages in the estimation model consist of:

a. Test data stationarity with the ADF test (Augmented Dickey Fuller test),

The ADF test can be formulated as follows;

$$
\Delta Y_{t}=a_{0}+z_{t}+a_{1} Y_{t-1}++\sum_{i=1}^{p} a i \Delta Y_{t}-1+\varepsilon_{t}
$$

If a0 is a constant, $\mathrm{t}$ is a deterministic trend, $\boldsymbol{\varepsilon}$ is an error term. If the autoregressive of $\mathrm{Y}$ $(\mathrm{Y}(\mathrm{t}-1)$ ) contains unit root (unit root), then the ratio $\mathrm{t}$ ( $\mathrm{t}$ ratio) for a1 should be consistent with the a1 hypothesis $=0$.

b. Cointegration test with Johansen's approach

Cointegration test with Johansen's approach using 2 statistical tests, namely Trace test and maximum Eigenvalue test. The two statistical tests can be written as follows: $\lambda_{\text {Trace }}(r)=-T \sum_{i=r+1}^{g} \ln \left(1-\lambda_{i}\right)$

$$
\lambda_{\text {Max }}(r, r+1)=-T \operatorname{In}\left(1-\lambda_{r+1}\right)
$$

c. Where $\lambda_{\tilde{i}}$ is estimated by the ordered eigenvalue with value. The standard approach to Johansen's method is the maximum likelihood (ML) procedure is to first calculate Trace and Maximum Eigenvalue statistics, then compare the appropriate critical values.

In the cointegration test stage, if there was cointegration between variables or cointegration rank more than zero, the analysis by Vector Error Correction Model. 


\section{Results and Discussion}

This involved testing the order of integration of the individual series under consideration. Saveral procedures for the test order of integreation have been developed. The most popular ones are Augmented Dickey-Fuller (ADF) test. Augmented Dickey-Fuller test relies on rejecting a null hypotesis of unit root (the series are non stationary) in favor of the alternative hypotheses of stationarity.

Very important thing to know about stationary properties of variables. Therefore, unit roor tests applied to examine the null hypothesis of having root. Data stationarity test results using the Augmented Dickey Fuller test (ADF test) give the following results:

Table 1 Data Stationarity Test Results with ADF Test

\begin{tabular}{ll}
\hline Variable & Conclusion \\
\hline EKS & Stationary at first difference \\
\hline FDI & Stationary at level \\
\hline IMP & Stationary at first difference \\
\hline PEK & Stationary at level \\
\hline
\end{tabular}

Source: Process data with Eviews software

Based on the table it can be concluded that in the stationarity level test, all variables are not stationary at the same degree of the four variables. Its only the economic growth variable (PEK) and Foreign Direct Investment (FDI) are stationary, while the export (EKS) and import variable (IMP) are not stationary (containing unit roots). Therefore, the non-stationary variables, namely the export (EKS) and import (IMP) variables, stationarity tests were carried out in first different. The result is from the two variables after the root test unit shows stationary (does not contain unit roots) at the level of $1 \%$ (First Difference). Therefore, it can be concluded that all variables are declared stationary on the degree of foreign direct investment (FDI) and economic growth (PEK) and stationary variables at first degree difference are exports (EKS) and imports (IMP). Thus, the data that has been transformed is feasible to be used in VAR or VECM analysis.

The next step is to do a cointegration test to test whether there is a relationship between variables. Cointegration test results using the Johansen method can be seen in tables 2 and 3.

Based on the results of the Co-integration Test with Johansen's method in tables 2 and 3, it can be concluded that the value of the trace test indicates the existence of 2 equations that are cointegrated at the level of $5 \%$. Based on the value of the max eigenvalue test also shows the existence of 1 equation which is cointegrated at the level of $5 \%$. So that based on the cointegration test it was found that there was a long-term relationship between the estimated variables.

Table 2 Unrestricted Cointegration Rank Test (Trace)

\begin{tabular}{ccccc}
\hline \hline $\begin{array}{c}\text { Hypothesized } \\
\text { No. of CE(s) }\end{array}$ & Eigenvalue & $\begin{array}{c}\text { Trace } \\
\text { Statistic }\end{array}$ & $\begin{array}{c}0.05 \\
\text { Critical Value }\end{array}$ & Prob. $^{* *}$ \\
\hline \hline None $^{*}$ & 0.688542 & 72.17886 & 47.85613 & 0.0001 \\
At most $1{ }^{*}$ & 0.407696 & 30.18525 & 29.79707 & 0.0451 \\
At most 2 & 0.269415 & 11.33078 & 15.49471 & 0.1920 \\
At most 3 & 0.000833 & 0.030013 & 3.841466 & 0.8624 \\
\hline \hline
\end{tabular}


Table 3 Unrestricted Cointegration Rank Test (Maximum Eigenvalue)

\begin{tabular}{ccccc}
\hline \hline $\begin{array}{c}\text { Hypothesized } \\
\text { No. of CE(s) }\end{array}$ & Eigenvalue & $\begin{array}{c}\text { Max-Eigen } \\
\text { Statistic }\end{array}$ & $\begin{array}{c}0.05 \\
\text { Critical Value }\end{array}$ & Prob. $^{* *}$ \\
\hline \hline None $^{*}$ & 0.688542 & 41.99361 & 27.58434 & 0.0004 \\
At most 1 & 0.407696 & 18.85447 & 21.13162 & 0.1011 \\
At most 2 & 0.269415 & 11.30076 & 14.26460 & 0.1398 \\
At most 3 & 0.000833 & 0.030013 & 3.841466 & 0.8624 \\
\hline \hline
\end{tabular}

Cointegration results in tables 2 and 3 show the value of the Trace Statistic from the Trace test of 72.17886 greater than the critical value at alpha 0.05 of 27.58434 , which means that in the system there is a cointegrated equation. Trace Statistic value of 30.18525 which is greater than the critical value at alpha 0.05 of 29.79707 shows that there is at least one cointegrated equation. After that, when viewed from the Maximum Eigenvalue test, the value of the Trace Statistic of 41.99361 shows that in the system there is one cointegrated equation.

Johansen Co-integration Test through cointegration test shows that in the four variables namely export, import, foreign direct investment (FDI) and economic growth in Indonesia 19802017 there is a long-term or cointegrated relationship. Thus in the context of this research, a Vector Error Correction Model (VECM) analysis can be applied.

To analyze the long-term and short-term relationships of the analysis of the relationship of the variables of export (EX), import (IMP), foreign direct investment (FDI) to economic growth (PEK) in Indonesia, parameter estimation is done using the Vector Error Correction Model (VECM) method. This model functions as a tool that is used when the variables observed are several variables that do not contain unit roots (stationary) even at different degrees. The following are the results of estimating the model of money demand using VECM as follows:

Table 4 Results of Estimates Using VECM Estimates

\begin{tabular}{cr}
\hline \hline Cointegrating Eq: & CointEq1 \\
\hline \hline PEK(-1) & 1.000000 \\
& $2.33 \mathrm{E}-07$ \\
EKS(-1) & $(1.4 \mathrm{E}-07)$ \\
& {$[1.63849]$} \\
& $-4.87 \mathrm{E}-07$ \\
& $(2.5 \mathrm{E}-07)$ \\
FDI $(-1)$ & {$[-1.97718]$} \\
& $-1.83 \mathrm{E}-07$ \\
& $(1.7 \mathrm{E}-07)$ \\
IMP(-1) & {$[-1.08528]$} \\
& -7.636518 \\
\hline
\end{tabular}


Table Cont...

\begin{tabular}{|c|c|c|c|c|}
\hline Error Correction: & $\mathrm{D}(\mathrm{PEK})$ & $\mathrm{D}(\mathrm{EKS})$ & $\mathrm{D}(\mathrm{FDI})$ & $\mathrm{D}(\mathrm{IMP})$ \\
\hline CointEq1 & $\begin{array}{r}-0.277388 \\
(0.30905) \\
{[-0.89756]}\end{array}$ & $\begin{array}{c}3458978 \\
(739700) \\
{[4.67619]}\end{array}$ & $\begin{array}{c}1070576 \\
(273618) \\
{[3.91266]}\end{array}$ & $\begin{array}{r}3043319 \\
(942359) \\
{[3.22947]}\end{array}$ \\
\hline $\mathrm{D}(\operatorname{PEK}(-1))$ & $\begin{array}{r}-0.140239 \\
(0.27287) \\
{[-0.51393]}\end{array}$ & $\begin{array}{c}-1830691 \\
(653123) \\
{[-2.80298]}\end{array}$ & $\begin{array}{c}-708506.8 \\
(241593) \\
{[-2.93264]}\end{array}$ & $\begin{array}{r}-1804440 \\
(832063) \\
{[-2.16863]}\end{array}$ \\
\hline $\mathrm{D}(\operatorname{PEK}(-2))$ & $\begin{array}{r}-0.220521 \\
(0.22894) \\
{[-0.96324]}\end{array}$ & $\begin{array}{c}-2317090 \\
(547955) \\
{[-4.22861]}\end{array}$ & $\begin{array}{c}-340252.3 \\
(202691) \\
{[-1.67867]}\end{array}$ & $\begin{array}{r}-1965810 \\
(698081) \\
{[-2.81602]}\end{array}$ \\
\hline $\mathrm{D}(\mathrm{EKS}(-1))$ & $\begin{array}{r}1.48 \mathrm{E}-07 \\
(1.4 \mathrm{E}-07) \\
{[1.05745]}\end{array}$ & $\begin{array}{r}0.383570 \\
(0.33424) \\
{[1.14759]}\end{array}$ & $\begin{array}{r}-0.096945 \\
(0.12364) \\
{[-0.78411]}\end{array}$ & $\begin{array}{r}1.092357 \\
(0.42581) \\
{[2.56534]}\end{array}$ \\
\hline $\mathrm{D}(\mathrm{EKS}(-2))$ & $\begin{array}{r}1.60 \mathrm{E}-07 \\
(1.4 \mathrm{E}-07) \\
{[1.17165]}\end{array}$ & $\begin{array}{r}0.282003 \\
(0.32630) \\
{[0.86426]}\end{array}$ & $\begin{array}{r}-0.181110 \\
(0.12070) \\
{[-1.50052]}\end{array}$ & $\begin{array}{r}0.662450 \\
(0.41569) \\
{[1.59361]}\end{array}$ \\
\hline $\mathrm{D}(\mathrm{FDI}(-1))$ & $\begin{array}{r}9.85 \mathrm{E}-10 \\
(2.5 \mathrm{E}-07) \\
{[0.00398]}\end{array}$ & $\begin{array}{r}0.761889 \\
(0.59305) \\
{[1.28470]}\end{array}$ & $\begin{array}{r}-0.477385 \\
(0.21937) \\
{[-2.17615]}\end{array}$ & $\begin{array}{r}0.360659 \\
(0.75553) \\
{[0.47736]}\end{array}$ \\
\hline $\mathrm{D}(\mathrm{FDI}(-2))$ & $\begin{array}{r}-5.59 \mathrm{E}-07 \\
(3.8 \mathrm{E}-07) \\
{[-1.46647]}\end{array}$ & $\begin{array}{r}-2.396182 \\
(0.91231) \\
{[-2.62649]}\end{array}$ & $\begin{array}{r}-0.881551 \\
(0.33747) \\
{[-2.61224]}\end{array}$ & $\begin{array}{r}-2.926271 \\
(1.16226) \\
{[-2.51773]}\end{array}$ \\
\hline $\mathrm{D}(\mathrm{IMP}(-1))$ & $\begin{array}{r}-1.44 \mathrm{E}-07 \\
(1.2 \mathrm{E}-07) \\
{[-1.15187]}\end{array}$ & $\begin{array}{r}-0.519559 \\
(0.29874) \\
{[-1.73917]}\end{array}$ & $\begin{array}{r}0.187714 \\
(0.11050) \\
{[1.69869]}\end{array}$ & $\begin{array}{r}-0.978035 \\
(0.38059) \\
{[-2.56982]}\end{array}$ \\
\hline $\mathrm{D}(\mathrm{IMP}(-2))$ & $\begin{array}{r}-4.06 \mathrm{E}-08 \\
(1.1 \mathrm{E}-07) \\
{[-0.36016]}\end{array}$ & $\begin{array}{r}-0.080581 \\
(0.26968) \\
{[-0.29880]}\end{array}$ & $\begin{array}{r}0.228886 \\
(0.09976) \\
{[2.29442]}\end{array}$ & $\begin{array}{r}-0.101257 \\
(0.34357) \\
{[-0.29472]}\end{array}$ \\
\hline $\mathrm{C}$ & $\begin{array}{r}-0.197241 \\
(0.80104) \\
{[-0.24623]}\end{array}$ & $\begin{array}{c}5331945 \\
(1917294) \\
{[2.78097]}\end{array}$ & $\begin{array}{r}505349.1 \\
(709216) \\
{[0.71255]}\end{array}$ & $\begin{array}{c}2705081 \\
(2442584) \\
{[1.10747]}\end{array}$ \\
\hline R-squared & 0.289604 & 0.647061 & 0.598792 & 0.575448 \\
\hline Adj. R-squared & 0.033861 & 0.520003 & 0.454357 & 0.422610 \\
\hline Sum sq. resids & 422.5407 & $2.42 \mathrm{E}+15$ & $3.31 \mathrm{E}+14$ & $3.93 \mathrm{E}+15$ \\
\hline S.E. equation & 4.111159 & 9840032. & 3639871. & 12535950 \\
\hline F-statistic & 1.132404 & 5.092645 & 4.145761 & 3.765070 \\
\hline
\end{tabular}


Table Cont...

\begin{tabular}{lrrrc} 
Log likelihood & -93.25426 & -607.3435 & -572.5356 & -615.8185 \\
Akaike AIC & 5.900243 & 35.27677 & 33.28775 & 35.76106 \\
Schwarz SC & 6.344629 & 35.72116 & 33.73214 & 36.20544 \\
Mean dependent & 0.080000 & 4951543 & 606857.1 & 4566029 \\
S.D. dependent & 4.182583 & 14202910 & 4927560 & 16497665 \\
\hline \hline Determinant resid covariance (dof adj.) & $4.18 \mathrm{E}+41$ & & \\
Determinant resid covariance & $1.09 \mathrm{E}+41$ & & \\
Log likelihood & -1852.214 & & \\
Akaike information criterion & 108.3551 & & \\
Schwarz criterion & 110.3104 & & \\
\hline \hline
\end{tabular}

The estimation VECM express below :

$=-0.277388(\mathrm{ECT})+2.33 \mathrm{E}-07(\mathrm{Eks}(-1))-4.87 \mathrm{E}-07(\mathrm{FDI}(-1))-1.83 \mathrm{E}-07(\operatorname{Imp}(-1))$

- 0.140239D(PEK(-1)) - 0.220521D(PEK(-2)) - 1.48E-07D(EKS(-1)) + 1.6E-07D(EKS(-2)) + 9.85E-

10D(FDI(-1)) - 5.59E-07D(FDI)-2)) - 1.44E-07D(IMP(-1)) - 4.06E-08D(IMP(-2)) - 0.197241.

Based on the results in the table 4 and the equation, it is known that the dependent variable of the equation is the variable of economic growth. It can be seen that the coefficient of ECT is 0.277388 . The statistical $t$ test is 0.89756 is less than $t$ value ( $t$ table). Its mean that the specification model was invalid.

In the long run only there was relationship between the foreign direct investment and economic growth. This results in line with research conducted by Kobrin (1997). Foreign Direct Investment have function as a medium for transferring needed resources, such as technology, managerial skills, marketing knowledge, export outlets and capital from industrialized countries to the developing countries. Therefore, FDI can increase economic growth. On the other hand, Indonesia is a developing country where it still needs a lot of funding to build every effort to improve the economy, road infrastructure, bridges, hospitals, public facilities, etc. Thus foreign direct investment (FDI) is needed especially for developing countries, especially Indonesia. Meanwhile, export and import have not significant effect to economy growth in Indonesia.

In the short run there were not relationship between export, import, foreign direct investment with economic growth in Indonesia. This results has opposite with study by Brueckner's and Lederman (2015); Astuti and Ayuningtyas (2018). The study found that in Sub-Saharan Africa there was a positive and significant effect of exports on economic growth. Variables import has not relationship with economic growth in Indonesia in the short run.

\section{Conclusions}

The purpose of this study is to analyze the relationship between exports, imports, and FDI with economic growth in Indonesia in the period 1980-2017 both in the long term and in the short term. Vector error correction model was employed to examines relationship between exports, imports, foreign direct investment and economic growth. The results of this study has shown that in the short term there was not relationship between export, imports, foreign direct investment and economic growth in Indonesia. In the long run there was negative relationship between 
foreign direct investment with economic growth. Meanwhilde, the specification model was invalid.

Based on the conclusions, there were suggestions belows:

1. Government must arrange the export and import activity to create economic growth every time in Indonesian economic.

2. Government must allocate and distribute flow of foreign direct investment to increase economic activity in every region in Indonesia.

3. Economic agent (producers) can focus to bring investment and international trade to stimulate economic growth in Indonesia.

\section{References}

Alfaro, L., Chandra, A., Kalemli-Ozcan, S., and Sayek, S. (2000). FDI and economic growth: the role of local financial markets. Harvard Business School. Working Paper. 01- 083.

Astuti, I. P., and Ayuningtyas, F. J. (2018). Pengaruh ekspor dan impor terhadap pertumbuhan ekonomi di Indonesia. Jurnal Ekonomi \& Studi Pembangunan, 19(1), 1-10.

Babatunde, M. A. (2014). Are exports and imports cointegrated? Evidence from Nigeria. Journal of International and Global Economic Studies, 7(2), 45-67.

Baliamoune-Lutz, M. N. (2004). Does FDI contribute to economic growth? Knowledge about the effects of FDI improves negotiating positions and reduces risk for firms investing in developing countries. Business Economics, 39(2), 49-57.

Blomström, M., and Kokko, A. (1996). The impact of foreign investment on host countries: a review of the empirical evidence. Policy Research Working Paper, 1745.

Brueckner, M, and Lederman, D. (2015). Trade openness and economic growth: Panel Data Evidence From Sub-Saharan Africa. Economica, 82, 1302 - 1323.

Carkovic, M., and Levine, R. (2005). Does foreign direct investment accelerate economic growth?. Does foreign direct investment promote development, 195.

Dritsaki, M., Dritsaki, C., and Adamopoulos, A. (2004). A causal relationship between trade, foreign direct investment and economic growth for Greece. American Journal of applied sciences, 1(3), 230-235.

Ekanayake, E. M. (1999). Exports and economic growth in Asia Developing Countries Cointegration and Error Correction Models, Journal of Economic Development 24(2): 43-56.

Ekanayake, E. M., Vogel, R., and Veeramacheneni, B. (2003). Openness and economic growth: Empirical evidence on the relationship Between output, inward FDI, and trade. Journal of Business Strategies, 20(1), 59.

Faridi, M. Z. (2012). Contribution of agricultural exports to economic growth in Pakistan. Pakistan Journal of Commerce E Social Sciences, 6(1).

Görg, H., and Greenaway, D. (2004). Much ado about nothing? Do domestic firms really benefit from foreign direct investment?. The World Bank Research Observer, 19(2), 171-197.

Hee, Y., and Lee, E. M. (2018). A Dynamic study between export and import from China to South Korea and economic growth in China. Jurnal Ekonomi dan Studi Pembangunan, 10(2), 117129.

Humpage, O. F. (2000). Do imports hinder or help economic growth. Federal Reserve Bank of Cleveland, March, 15.

Kholis, Muhammad. (2012). Dampak Foreign Direct Investment Terhadap Pertumbuhan Ekonomi Indonesia. Jurnal Organisasi dan Manajemen, 8, 111-120. 
Kobrin, S.J. (1997). 'The architecture of globalization: State sovereignty in a networked global economy', in Dunning, J., Governments, Globalization and International Business, Oxford: Oxford University Press, 147-163.

Kogid, M., Mulok, D., Ching, K. S., Lily, J., Ghazali, F., \& Loganathan, N. (2011). Does import affect economic growth in Malaysia. Empirical Economics Letters, 10(3), 297-307.

Kutan, A. M., and Vukšić, G. (2007). Foreign direct investment and export performance: empirical evidence. Comparative Economic Studies, 49(3), 430-445.

Liu, X., Wang, C., and Wei, Y. (2001). Causal links between foreign direct investment and trade in China. China economic review, 12(2-3), 190-202.

Md, M. A., and Suleiman, N. N. (2016). The relationship among export, import, capital formation and economic growth in Malaysia. Journal of Global Economics.

Mukhlis, Imam, Timbul Hamonangan Simanjuntak, and Teguh Prasetyo, (2018). The Analysis of the Bank Interest Influence and Exchange Rate Towards Composite Stock Price Index in Indonesia Using Vector Error Correction Model Approach, The First International Research Conference on Economics and Business, 127-139, downloaded from https://knepublishing.com/index.php/Kne-Social/article/view/1879/4487

Mukhlis, I., and Simanjuntak, T. H. (2014). The Cointegration Analysis of the Relationships between Foreign Direct Investment Inflow and Gross Domestic Product in Indonesia, Journal of Economics and Sustainable Development, Vol 5,No 6, 29-34

Mohsen, A. S. (2015). Effect of exports and investment on the economic growth in Syria, International Journal of Management, accounting, and economics. 2(6).

Onkuwa, K. and Zoral, K. Y. (2009). Foreign direct investment and imports growth in Turkey. Journal of Yasar Universit..4(15), 2357-2380.

Salvatore, Dominick, 1990. Ekonomi Internasional. Cetakan Kedua. Sitompul, Rudy (Penerjemah), Penerbit Erlangga. Jakarta.

Tong, J. (1995). Price change of stock and economic running price change of stock and economic running. Tainjin: Nankai University Press.

Vohra, R. (2001). Export and economic growth: Further time series evidence from less-developed countries. International Advances in Economic Research, 7(3), 345-350.

Yin, X., and Yin, X. (2005). Can developing countries benefit from export promotion?. Journal of Economic Studies, 32(1), 60-80.

Zhang, K. H. (2006). Foreign direct investment and economic growth in China: A panel data study for 1992-2004. In Conference of WTO, China and Asian Economies, University of International Business and Economics, June,24-26.

Zhang Q. and Felmingham, B. (2002). The role of FDI, exports and spillover effects in the regional development of China. Journal of Development Studies, 38(4), 157-178. 